\title{
Does Government Borrowing Crowd out Private Sector Credit in
}

\section{Pakistan}

\author{
Sajjad Zaheer * $\quad$ Fatima Khaliq $^{\dagger} \quad$ Muhammad Rafiq ${ }^{\ddagger}$
}

\begin{abstract}
We investigate the impact of government borrowing from the scheduled banks on the credit to private sector in Pakistan, using monthly data from 1998:M6 to 2015:M12. We find that a one percentage point growth in the government borrowing leads to 8 basis points crowding out of the private sector credit in four months. Albeit small, there is negative impact of government borrowing on the private sector credit. The results remain unchanged even after implementation of the interest rate corridor since August 2009.
\end{abstract}

Keywords: Private sector credit, Government policy and regulation, Government borrowing, emerging economies.

\section{Introduction}

Borrowing by the governments in domestic market is a common phenomenon both in developed and developing countries. In fact, developed countries have relatively larger share of such borrowing as their spending on the provision of public services is high. On the other hand, developing economies mostly borrow to finance infrastructure projects with longer gestation period which loosens their control over expenditures. This in addition to limited revenue generation necessitates borrowing for deficit financing (Morrison, 1982; Ramamurti, 1992; Bua, Pradelli, \& Presbitero, 2014). Pakistan is no exception. The rigidities in country's tax collection system along with liberalization of trade regime have led to loss of a considerable amount of revenue sources. On the other hand, public sector expenditure has remained rigid and high, leading to large fiscal deficits. Within these constraints, government relies on domestic and international borrowing to finance the budget deficit.

The financing of budget deficit through commercial bank borrowing is believed to crowd out private sector credit. These concerns and their adverse implications have been highlighted in various flagship publications of the State Bank of Pakistan as well ${ }^{1}$. It is alleged that government borrowing has led the commercial banks to earn massive risk free returns, making them captive to hassle free profit making. Resulting complacency on commercial banks' part has lead to crowding out of private sector credit. On the contrary,

\footnotetext{
*Joint Director, State Bank of Pakistan, Karachi. E-mail: sajjad.zaheer@sbp.org.pk

${ }^{\dagger}$ Deputy Director, State Bank of Pakistan, Karachi.

$\ddagger$ Senior Joint Director, State Bank of Pakistan, Karachi.

The authors are thankful to Syed Kalim Hyder, Jameel Ahmed and Muhammad Nadim Hanif.

${ }^{1}$ SBP Monetary Policy Statements for February 2013, August 2012, and July 2011.
} 
it has been argued that the lending to the government increases the risk appetite of the banks and consequently banks may increase lending to private sector.

This premise, if true, may dampen the crowding out and even result in crowding in. In this background, it is very much important to explore whether government borrowing leads to crowding out or crowding in.

Generally, the literature focuses on estimating the impact of government borrowing on the private investment. The government borrowing may crowd out private investment or it may complement the latter (crowding in). Apart from crowding out and crowding in channel, literature also discusses the importance of financing of fiscal expenditure, since the financing channel is of great importance for the size and sign of the fiscal multiplier (Choudhary, Khan, Pasha, \& Rehman, 2016).

The focus of our study, however, is to investigate the impact of the government borrowing from scheduled banks on the availability of credit to the private sector, particularly the magnitude of crowding out. That is, when the government increases its borrowing from scheduled banks, the available funds for the private sector may shrink, leading to a decrease in the quantity of loans to be given to the private sector ${ }^{2}$. Another motivation for this study is driven from the regime change in 2009 - the introduction of interest rate corridor. After the adoption of a sort of interest rate targeting regime, the central bank is bound to provide/absorb liquidity, in case of shortage/excess, to/from the market for keeping interbank overnight weighted average repo rate around the policy rate. Hence, a priori, after the implementation of the interest rate corridor regime, the crowding out effect of the government borrowing may fade away. In this respect, our study contributes to address this gap by investigating how this structural change in the monetary policy regime has impacted the crowding out/in hypothesis.

The results of our study show that for every 1 percentage point increase in the growth of government borrowing from the banking system there is, on average, 8 basis points decrease in private sector credit growth in four months. After the introduction of the interest rate corridor the coefficient for the government borrowing from the banking system is not significantly different from that of per-corridor period.

\section{Review of Literature}

The literature on crowding out generally identifies two channels: price channel of crowding out and quantity channel of crowding out. Classical and no-classical economists advocate free markets and supports price channel of crowding out i.e. government borrowing may crowd out private investment through increase in interest rate due to reduced level of funds available for private sector. On the other hand, quantity channel analyzes the magnitude of the crowding out effect of government borrowing from the banks on private sector credit (Emran, Farazi, et al., 2009).

The empirical literature investigating the quantity approach is rather limited. By focusing on the volume of credit to the private sector, (Emran et al., 2009) explored the

\footnotetext{
${ }^{2}$ Alternatively, when government borrows from the banks, interest rate rises, and cost of borrowing from the banks goes up leading to a decrease in demand for bank loans by the corporate firms.
} 
crowding out of private credit in developing countries. The results showed that there is significant crowding out effect of government borrowing from domestic banks on private credit. Fayed (2013); Shetta and Kamaly (2014) established same results for Egypt.

Government borrowing and its crowding out impact on private investment has been intensively discussed in literature especially for less developed countries (LDCs). However, various studies provide different results for developing countries including evidences both of crowding in and crowding out (Choudhary et al., 2016; Atukeren, 2005). Similarly, studies have also been carried out for developed countries, which came to the same conclusion (Mahmoudzadeh, Sadeghi, \& Sadeghi, 2017; H. Ahmed \& Miller, 2000).

Some studies have also been conducted to investigate the phenomenon of crowding out in Pakistan. For instance, S. Khan et al. (2016) developed a theoretical model for dominant borrower (government) from banks for financing of fiscal deficit. The study also proved empirically that dominant borrower Syndrome (DBS) leads to crowding out of private sector investment and rise in interest rate spreads.

J. Ahmed (2016), while estimating banks supply side equation, also found that government borrowing from banks had crowding out effect on private sector credit. R. E. A. Khan and Gill (2009) examined the existence of crowding-out effect of public borrowing on private investment in Pakistan in the long run, using co-integration test. They concluded crowding in instead of crowding out of private sector investment in the long run. Their conclusion was based on the evidence of excess liquidity in the banking system and significant development expenditure resulting in "positive externalities". Hussain, Muhammad, Akram, and Lal (2009), using co-integration technique, concluded that expenditure on defense and debt serving crowds-out private investment whereas spending on infrastructure, health and education crowds-in private investment in the long run. However, using ECM technique they concluded that results were insignificant in the short term. Saeed, Hyder, Ali, and Ahmad (2006) estimated the impact of public investment on private investment in agriculture and manufacturing sector and in overall economy using unrestricted structural VAR models. Their study concluded that the increase in public investment persuades private investment in agriculture sector (i.e. crowding in) and it dampens private investment in manufacturing sector (i.e. crowding-out). For overall economy, no significant impact of public investment on private investment was found. Rashid and Ahmad (2005) employed impulse response function (IRF), variance decompositions (VDC) and multivariate co-integration approach to examine the relationship between public and private investment. His empirical results showed that public investment crowds in private investment in the long run. The estimates of VDC presented weak proof, whereas IRFs supported a positive response of private investment to a shock of public investment. Naqvi (2002) examined the relationship between the GDP, fixed capital formation and public capital formation by using co-integration and VAR. His paper provided evidence that government complements private investment in the long run, in Pakistan.

Hyder and Qayyum (2001) tested the crowding-out hypothesis for Pakistan by using vector error-correction (VEC) framework and impulse response function. Their findings confirmed the complementaries between public and private investment. Looney (1995) investigated the effect of public sector crowding-out of private capital formation for man- 
ufacturing sector in Pakistan. By using Granger causality test his results suggested that private investment in large scale manufacturing (LSM) underwent real crowding out due to the government's non-infrastructure investment projects. Burney, Yasmeen, and Niazi (1989) investigated the empirical relationship between government budget deficit and nominal interest rates. They concluded that there is no relationship between the overall government budget deficit and the nominal interest rates. However, budget deficit has positive impact on the nominal interest rates only under specific circumstances, such as knowledge of future inflation rate. Moreover, the study linked the deficit with higher nominal interest rate only if the deficit was financed by bank borrowing, hence, ending up in crowding out of private investment and consumption expenditures. Saleem (2016) finds a negative short and long run relationship exists between private investment and real discounted rate of return. Banks also tighten lending conditions to private sector subject to their perception about risks (Nguyen \& Vo, 2018).

Empirical studies carried out for Pakistan so far depict mixed results, mostly supporting crowding in of private investment as a result of fiscal spending, therefore it is difficult to generalize the findings at this stage. This study is another effort of investigating crowding out of private sector credit by the government borrowing from banks and to estimate extent of crowding out, if any. We also explore the impact of introduction of interest rate corridor regime upon crowding in/out hypothesis in Pakistan.

\section{Some Stylized Facts}

This section presents stylized facts about the revenue position of the government, government borrowing from the scheduled banks, private sector credit and a review of regime shift in monetary policy operation in Pakistan during 1998 to 2015. Brief descriptive analysis of these variables aims at providing an understanding of the trends in these variables over time.

Revenue generation capacity has remained one of the major concerns for Pakistan. Structural problems like narrow tax base, tax evasion and administrative weaknesses, have taken a toll on tax collection. These issues kept tax to GDP ratio lower in Pakistan. Apart from taxes, decline in statutory tariff rates have caused gradual decrease in government's revenue sources, which was largely due to liberalization of trade regime ${ }^{3}$.

Due to limited revenue resources, government borrowing from scheduled banks has remained dominant source of financing the budget deficits in Pakistan. Government, in recent years, has opted to borrow more from domestic sources whereas credit to private sector has expanded at slower pace. Besides crowding out the private sector credit, government fiscal operations also created substantial challenges for monetary management through abrupt movements in market liquidity and growth in monetary variables.

\footnotetext{
${ }^{3}$ The corporate tax regime has also been relaxed since 1992-93. The tax rate on banking, public and private companies has been reduced from 66, 44 and 55 percent in 1992-93 to a flat rate of 35 percent for all categories of corporate entities whereas the tariff rate, which was 80 percent in 1993-94, was curtailed to 25 percent by 2006-2007. Similarly, the effective rates on dutiable imports and total imports were respectively slashed from 38 and 25 percent in 1993-94 to 12 and 7 percent in 2006-2007.
} 
Apart from these facts, SBP also adopted a new framework for management of its monetary operations. It introduced, with effect from August 17, 2009, a 300 basis points interest rate corridor for the money market overnight repo rate. In this framework, SBP reverse repo rate (discount rate) represented a 'ceiling' rate and the SBP repo rate provided a 'floor' to the corridor. With effect from February 11, 2013, the width of the corridor was reduced to 250 basis points. The width was further reduced to $200 \mathrm{bps}$ in May 2015. Further refinement in this framework was announced in May 2015 by setting Target rate (policy rate) between the ceiling and floor rates of the corridor. In this framework SBP uses its liquidity management tools more frequently to keep the money market weighted average overnight rate close to the target rate. Before the introduction of corridor, the overnight money market repo rate remained highly volatile, which often diluted the monetary policy signals and weakened the transmission of monetary policy.

Thus after the introduction of the corridor framework, the central bank focuses on keeping the interbank overnight repo rate within the ceiling and the floor rate of this corridor. This is primarily a regime shift from monetary targeting to a sort of interest rate targeting ${ }^{4}$. Generally, the liquidity in the interbank may be affected through various endogenous and exogenous factors. For instance, various tax payments by the depositors to the government decrease the liquidity in the interbank. Similarly, government auction (borrowing) of treasury bills or bonds in the primary market drains interbank funds causing interest rate to surge in money market. However, after the adoption of an interest rate targeting type regime, the central bank is bound to provide/absorb liquidity, in case of shortage/excess, to/from the market for keeping interbank overnight weighted average repo rate around the policy rate. Hence, a priori, after the implementation of the interest rate corridor regime, the crowding out effect of the government borrowing may weaken. It is, therefore, very much interesting to investigate how this structural change in the monetary policy regime have impacted the crowding out hypothesis for the case of Pakistan.

\section{Data and Econometric Specification}

The period of analysis is from June 1998 to December $2015^{5}$. Generally, the empirical work on crowding out used theoretical vector autoregressive (VAR) models or vector error correction model (VECM) for Pakistan. However, since we are interested in equilibrium private sector credit response to a monetary policy change,we followed a variant of theoretical model by Ehrmann, Gambacorta, Martínez-Pagés, Sevestre, and Worms (2001) in which equilibrium private sector credit equation is derived from loan demand and loan supply equations. However, instead of using cost of government borrowing as a determinant of private sector credit we used volume of the government borrowing for the same

\footnotetext{
${ }^{4}$ Although analysis post changes in Interest Rate Corridor (IRC) introduced in May 2015 would have been more pertinent for our study, however, due to data constraints we have used information since the introduction of corridor in Pakistan for estimation purposes.

${ }^{5}$ Our analysis starts from 1998 as prior to this we do not have break up of government borrowing from scheduled banks and State Bank of Pakistan.
} 
purpose. Thus, we have regressed growth in private sector credit mainly on the growth in government budgetary borrowing. We also included an array of supply and demand side control variables. Specifically, we used discount rate ${ }^{6}$ to control for the monetary policy and total deposits net of banks' balances with SBP ${ }^{7}$ to measure the impact of lending capacity of the scheduled banks. Similarly, we employed headline inflation and industrial production/ large scale manufacturing index to control for demand side dynamics. For estimation purposes, we employed OLS upon the specification 1, closely following (Kashyap \& Stein, 2000):

$$
\begin{aligned}
P S C_{t}=c+\sum_{j=1}^{m} \alpha_{j} P S C_{t-j}+\sum_{j=0}^{m} \mu_{j} G B_{t-j}+\sum_{j=0}^{m} \varphi_{j} \Delta D I S R_{t-j}+\sum_{j=0}^{m} \gamma_{j} L C_{t-j} \\
+\sum_{j=0}^{m} \delta_{j} I P L S M_{t-j}+\sum_{j=0}^{m} \pi_{j} C P I_{t-j}+\sum_{k=1}^{1} 1 \rho_{k} \text { Month }_{k}+\epsilon_{t}
\end{aligned}
$$

Where,

$P S C_{t}=$ The dependent variable is the monthly growth of the total amount of loans granted to the private sector by the banking system in month $t$,

$G B_{t-j}=$ the monthly growth in the government borrowing from the scheduled banks in month $t-j$,

$\delta D I S R_{t-j}=$ the change in discount rate in month $t-j$,

$L C_{t-j}=$ the growth in lending capacity measured by the total deposits net of reserves in month $t-j$,

IPLSM $M_{t-j}=$ Growth in the index of Industrial Production/Large Scale Manufacturing in month $t-j$,

$C P I_{t-j}=$ CPI inflation in month $t-j$

Months= dummy for month $k$

$C=$ intercept, and

$m$ (maximum lag) is set to four.

\footnotetext{
${ }^{6}$ Since the changes in corridor framework in May 2015 policy rate is different from the discount rate, which is the penal rate.

${ }^{7}$ Total deposits have been netted out with banks' balances with SBP as given in monetary survey. In this data, banks' balances with SBP are not segregated between required and excess reserves that is why reserves and balances have been used interchangeably.
} 
As discussed earlier, the paper also estimates the impact of shift in monetary regime on private sector credit due to introduction of interest rate corridor in August 2009. To control for this regime shift we introduced a dummy for interest rate corridor which takes a numerical value of one during September 2009 and December 2015, and zero otherwise. Moreover, we introduced interaction between this dummy and government borrowing to estimate the difference, if any, of government borrowing on the private sector credit after the implementation of the interest rate corridor. In this particular case we estimated the following.

$$
\begin{aligned}
& P S C_{t}=c+\sum_{j=1}^{m} \alpha_{j} P S C_{t-j}+\sum_{j=0}^{m} \mu_{j} G B_{t-j}+\sum_{j=0}^{m} \varphi_{j} \Delta D I S R_{t-j}+\sum_{j=0}^{m} \gamma_{j} L C_{t-j} \\
& +\sum_{j=0}^{m} \delta_{j} I P L S M_{t-j}+\sum_{j=0}^{m} \pi_{j} C P I_{t-j}+I R C\left(\omega+\sum_{j=0}^{m} \mu_{j} G B_{t-j}\right)+\sum_{k=1}^{1} 1 \rho_{k} \text { Months } s_{k}+\epsilon_{t}
\end{aligned}
$$

IRC is a dummy to control for interest rate corridor regime. The interaction term $I R C * G B_{t-j}$ is used to gauge the differential impact of the government borrowing on the private sector credit during interest rate corridor regime.

\section{Results}

In Table 1 (Annexure A) baseline model shows the results of specification (1) with and without including time trend in the model. Lagged values of dependent variable i.e. private sector credit growth have a positive impact on its current period growth. Our main coefficient of interest is $\mu$ which measures the potency of the crowding out or crowding in. This coefficient is -0.082 demonstrating a negative and statistically significant impact of government budgetary borrowing on the private sector credit. More specifically, a 1 percentage point growth in government borrowing from scheduled banks, crowds out growth in private sector credit by around 8 basis points in four months ${ }^{8}$. Although this coefficient is economically small, it is statistically significant and robust to changes in specifications. Thus, the coefficient suggests the direction of the impact of government borrowing on private sector credit. J. Ahmed (2016) also finds that if real interest rate on treasury bills increases by 1 percentage point, it would decrease the real private sector credit by 3 basis points. Excluding last couple of years of government performance, government spending on non-developmental projects due to certain pressures could have been a main reason for crowding out phenomenon. As it is believed that government developmental spending is helpful for development of private sector and its demand for bank financing.

\footnotetext{
${ }^{8}$ If annualized this is equal to 24 basis points decrease in private sector credit growth against four percentages points increase in government borrowing growth.
} 
On the other hand, lending capacity of the banks has a significant positive effect on private sector credit. In particular, a 1 percentage point growth in lending capacity increases the growth in private sector credit by 87 basis points in four months time. Although the coefficient for the discount rate appears negative but is statistically insignificant. A potential reason could be that there is a very low variability in the discount rate during the period under consideration. Moreover, the impact of monetary policy may not be perfectly gauged using aggregate data. In this regard panel data give better results. For instance, Zaheer, Ongena, and Van Wijnbergen (2013) show that monetary policy in Pakistan works mostly through small banks as after a monetary tightening small banks are more likely to cut their private sector credit. On demand side, industrial production /large scale manufacturing index has significantly positive impact on the lending to the private sector credit. The estimated coefficient for the variable is 0.124 . The impact of $\mathrm{CPI}$ on the private sector credit is statistically insignificant. We also included the time trend in the model to check the robustness. The results support our earlier findings on the crowding out.

Table 2 in Annexure A exhibits the results of the specification (2), where we attempted to disentangle the impact of IRC. Again, the main coefficient of interest is $\mu$ which gauges the strength of the crowding out impact. The coefficient shows a negative and statistically significant impact of government borrowing on the lending to the private sector by the banks. Thus before the implementation of the interest rate corridor a 1 percentage point increase in government borrowing from the banks crowded out the private sector credit by around 8.2 basis points in four months. After the introduction of interest rate corridor in August 2009, the coefficient of the crowding out impact of government borrowing remains statistically significant and the coefficient is -0.081 . It shows that statistically there is no significant difference between the coefficient of government borrowing, before and after the introduction of interest rate corridor. The possible reason for this indifferent result may be that initially middle of the corridor was not explicitly announced as the target rate. In this period the weighted average overnight rate mostly remained close to the discount rate due to a host of other factors ${ }^{9}$. Thus, it is potential subject for future research, as more data would be available in future for post-policy rate period.

\section{Conclusion}

The impact of government budgetary borrowing on the private sector credit has been a subject of interest of researchers, especially in developing countries. The main premise is that government borrowing leads to crowding out of private sector credit due to reduced availability of the loan-able funds. On the other hand there are arguments that investment in government securities increases the risk appetite of the banking sector and banks' desire to lend to relatively risky avenues.

We investigated private sector credit response to the government borrowing, after controlling for an array of banking and macro variables. We found that in Pakistan, government borrowing from the scheduled banks crowds out private sector credit. To decipher

\footnotetext{
${ }^{9}$ Less developed market, liquidity constraints, exchange rate considerations etc.
} 
the impact of change in monetary regime we use dummy variable for interest rate corridor introduced by the SBP in August 2009. The results show that there is no significant difference in the impact of government borrowing on the private sector credit before and after the implementation of the interest rate corridor. Hence it may be concluded that there is, in general, a negative impact of government borrowing on the private sector credit ${ }^{10}$.

\section{References}

Ahmed, H., \& Miller, S. M. (2000). Crowding-out and crowding-in effects of the components of government expenditure. Contemporary Economic Policy, 18(1), 124-133.

Ahmed, J. (2016). Credit conditions in Pakistan: Supply constraints or demand deficiencies? The Developing Economies, 54(2), 139-161.

Atukeren, E. (2005). Interactions between public and private investment: Evidence from developing countries. Kyklos, 58(3), 307-330.

Bua, G., Pradelli, J., \& Presbitero, A. F. (2014). Domestic public debt in low-income countries: Trends and structure. The World Bank.

Burney, N. A., Yasmeen, A., \& Niazi, M. K. (1989). Government budget deficits and interest rates: An empirical analysis for Pakistan. The Pakistan Development Review, 28(4), 971-980.

Choudhary, M. A., Khan, S., Pasha, F., \& Rehman, M. (2016). The dominant borrower syndrome. Applied Economics, 48(49), 4773-4782.

Ehrmann, M., Gambacorta, L., Martínez-Pagés, J., Sevestre, P., \& Worms, A. (2001). Financial systems and the role of banks in monetary policy transmission in the euro area. ECB working paper.

Emran, M. S., Farazi, S., et al. (2009). Lazy banks? government borrowing and private credit in developing countries. Institute for International Economic Policy Working Paper, 9 .

Fayed, M. E. (2013). Crowding out effect of public borrowing: The case of Egypt. International Research Journal of Finance and Economics, 107(1), 28-38.

Hussain, A., Muhammad, S. D., Akram, K., \& Lal, I. (2009). Effectiveness of government expenditure crowding-in or crowding-out: Empirical evidence in case of Pakistan. European Journal of Economics, Finance and Administrative Sciences, 16.

Hyder, K., \& Qayyum, A. (2001). Crowding-out hypothesis in a vector error correction framework: A case study of Pakistan. The Pakistan Development Review, 633-650.

Kashyap, A. K., \& Stein, J. C. (2000). What do a million observations on banks say about the transmission of monetary policy? American Economic Review, 90(3), 407-428.

Khan, R. E. A., \& Gill, A. R. (2009). Crowding out effect of public borrowing: A case of Pakistan.

Khan, S., et al. (2016). The dominant borrower syndrome: The case of Pakistan. SBP Working Paper Series 77.

\footnotetext{
${ }^{10}$ This paper is from working paper series of SBP.
} 
Looney, R. E. (1995). Public sector deficits and private investment: A test of the crowdingout hypothesis in Pakistan's manufacturing industry. The Pakistan Development Review, 277-297.

Mahmoudzadeh, M., Sadeghi, S., \& Sadeghi, S. (2017). Fiscal spending and crowding out effect: A comparison between developed and developing countries. Institutions and Economies, 31-40.

Morrison, T. K. (1982). Structural determinants of government budget deficits in developing countries. World Development, 10(6), 467-473.

Naqvi, N. H. (2002). Crowding-in or crowding-out? Modelling the relationship between public and private fixed capital formation using co-integration analysis: The case of Pakistan 1964-2000. The Pakistan Development Review, 255-275.

Nguyen, V. N. T., \& Vo, L. H. (2018). Bank lending decision under uncertainty: The case of borrowers from european peripheral countries in the sovereign debt crisis. Journal of Finance and Economics Research, 3(1), 1-20.

Ramamurti, R. (1992). Why are developing countries privatizing? Journal of International Business Studies, 23(2), 225-249.

Rashid, A., \& Ahmad, I. (2005). Public/private investment linkages: A multivariate cointegration analysis. The Pakistan Development Review, 805-817.

Saeed, N., Hyder, K., Ali, A., \& Ahmad, E. (2006). The impact of public investment on private investment: A disaggregated analysis. The Pakistan Development Review, 639-663.

Saleem. (2016). Impact of monetary policy on private investment: Evidence from pakistan. Journal of Finance and Economics Research, 2(2), 134-146.

Shetta, S., \& Kamaly, A. (2014). Does the budget deficit crowd-out private credit from the banking sector? The case of Egypt. Topics in Middle Eastern and North African Economies, 16(2), 251-279.

Zaheer, S., Ongena, S., \& Van Wijnbergen, S. (2013). The transmission of monetary policy through conventional and islamic banks. International Journal of Central Banking, 8(5), 175-224. 


\section{Annexure A}

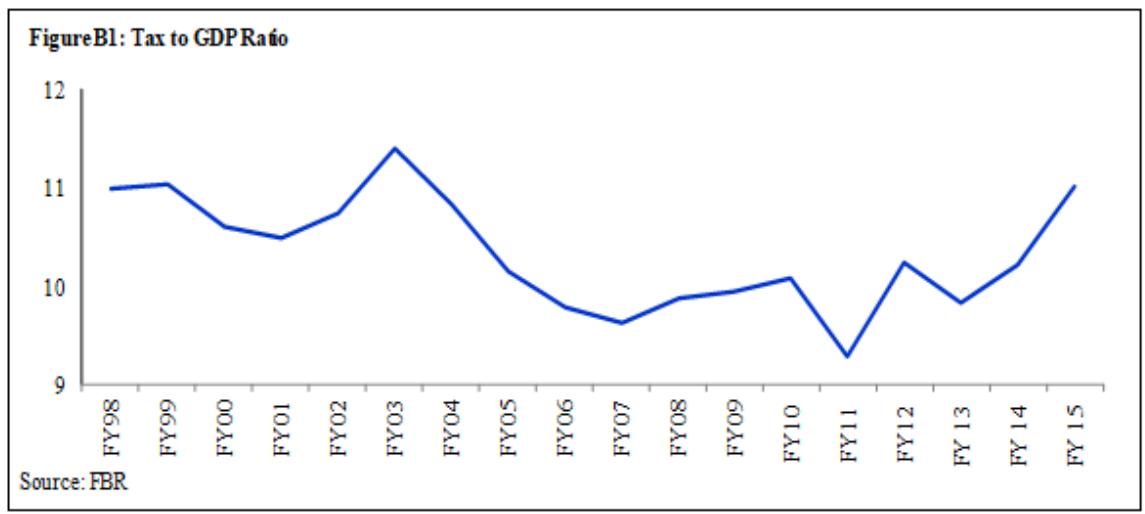

\section{Figure B2: Credit to Private Sector and Govemment Borrowing}
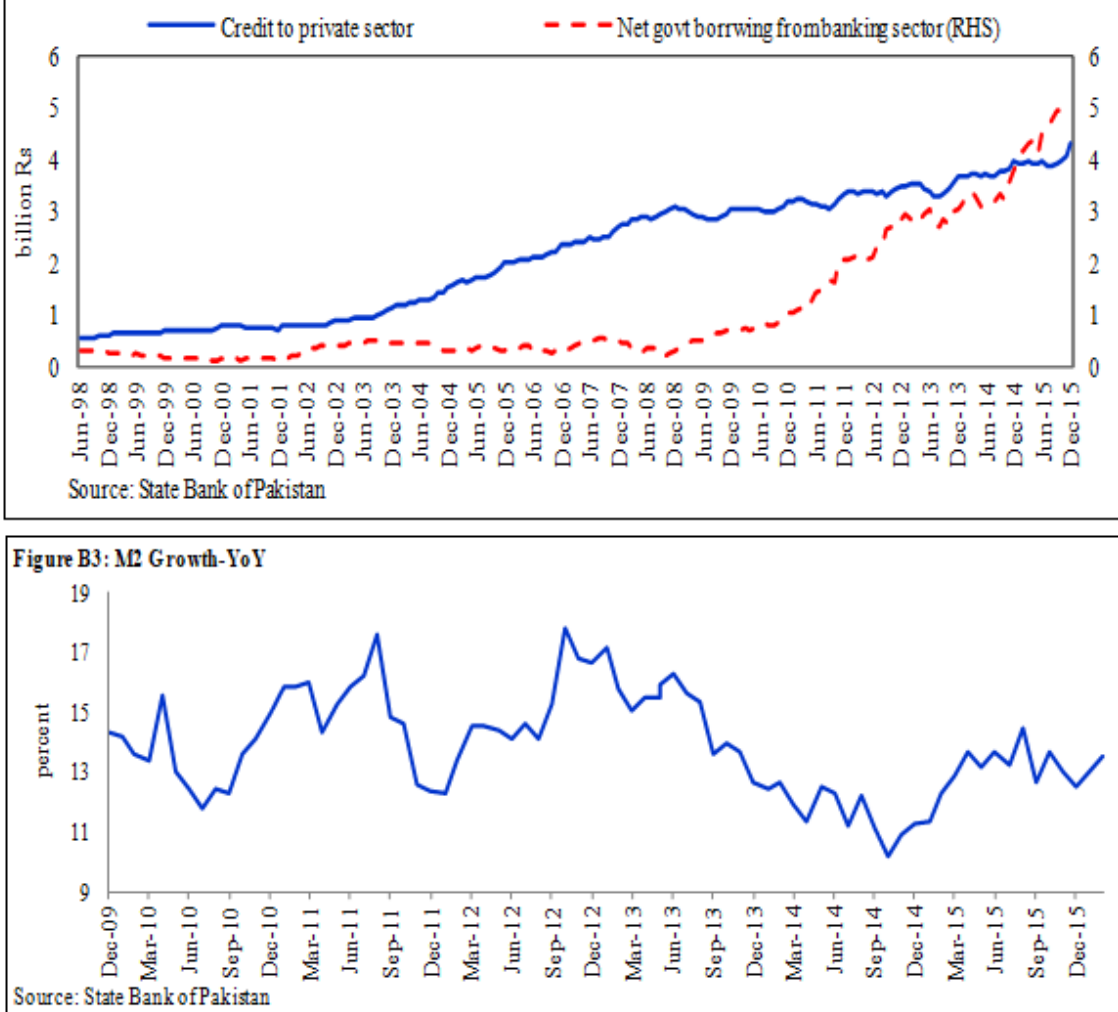
Table 1

\begin{tabular}{|c|c|c|c|c|c|}
\hline \multirow[t]{2}{*}{ S.No. } & \multirow{2}{*}{ Variable name } & \multicolumn{2}{|c|}{ Model (1) } & \multicolumn{2}{|c|}{ Model (1) with time trend } \\
\hline & & Coefficients & Probability & Coefficients & Probability \\
\hline 1 & $\mathrm{C}$ & 1.830 & 0.000 & 2.172 & 0.000 \\
\hline 2 & $\sum_{j=1}^{m} \alpha_{j} P S C_{t-j}$ & 0.315 & 0.013 & 0.270 & 0.038 \\
\hline 3 & $\sum_{j=0}^{m} \mu_{j} G B_{t-j}$ & -0.081 & 0.001 & -0.080 & 0.002 \\
\hline 4 & $\sum_{i=0}^{m} \varphi_{j} \Delta D I S R_{t-j}$ & -0.067 & 0.862 & -0.073 & 0.849 \\
\hline 5 & $\sum_{j=0}^{m} \gamma_{j} L C_{t-j}$ & 0.869 & 0.000 & 0.906 & 0.000 \\
\hline 6 & $\sum_{j=0}^{m} \delta_{j} I P L S M_{t-j}$ & 0.124 & 0.006 & 0.122 & 0.007 \\
\hline 7 & $\sum_{j=0}^{m} \pi_{j} C P I_{t-j}$ & -0.090 & 0.693 & -0.002 & 0.995 \\
\hline$R^{2}$ & & 0.770 & & 0.780 & \\
\hline Adjust & $\mathrm{d} R^{2}$ & 0.720 & & 0.720 & \\
\hline Durbir & Watson stat & 2.050 & & 2.050 & \\
\hline Month & y Dummies & Yes & & Yes & \\
\hline Trend & & No & & Yes & \\
\hline \multicolumn{6}{|c|}{$\begin{array}{l}\text { The dependent variable } P S C_{t} \text { is the growth in the total amount of the loans granted to } \\
\text { the private sector by banking system in month } t \text {. The independent variables are: } \\
P S C_{t-j} \text { which is the growth of the total amount of the loans granted to the private } \\
\text { sector by banking system in month } t-j, G B_{t-j} \text { which is the growth in government } \\
\text { borrowing in month } t-j, L C_{t-j} \text { which is the growth in the lending capacity of the banks } \\
\text { measured by the total deposits net of reserves. } I P L S M_{t-j} \text { which is growth in the index } \\
\text { of Industrial Production/Large Scale Manufacturing and } C P I_{t-j} \text { which is CPI inflation. } \\
\text { The estimations use } 206 \text { monthly observations. }\end{array}$} \\
\hline
\end{tabular}

Table 2

\begin{tabular}{|c|c|c|c|c|c|}
\hline \multirow[t]{2}{*}{ S. No. } & \multirow[t]{2}{*}{ Variable name } & \multicolumn{2}{|c|}{ Model (2) } & \multicolumn{2}{|c|}{ Model (2) with time trend } \\
\hline & & Coefficients & Probability & Coefficients & Probability \\
\hline 1 & $\mathrm{C}$ & 1.925 & 0.000 & 1.833 & 0.000 \\
\hline 2 & $\sum_{j=1}^{m} \alpha_{j} P S C_{t-j}$ & 0.232 & 0.090 & 0.228 & 0.098 \\
\hline 3 & $\sum_{j=0}^{m} \mu_{j} G B_{t-j}$ & -0.082 & 0.004 & -0.083 & 0.004 \\
\hline 4 & $\sum_{j=0}^{m} \varphi_{j} \Delta D I S R_{t-j}$ & -0.170 & 0.675 & -0.186 & 0.651 \\
\hline 5 & $\sum_{j=0}^{m} \gamma_{j} L C_{t-j}$ & 0.900 & 0.000 & 0.896 & 0.000 \\
\hline 6 & $\sum_{j=0}^{m} \delta_{j} I P L S M_{t-j}$ & 0.129 & 0.004 & 0.130 & 0.004 \\
\hline 7 & $\sum_{j=0}^{m} \pi_{j} C P I_{t-j}$ & -0.002 & 0.992 & -0.015 & 0.952 \\
\hline 8 & $I R C$ & 0.342 & 0.164 & -0.418 & 0.282 \\
\hline 9 & $I R C * \sum_{j=0}^{m} \mu_{j} G B_{t-j}$ & 0.001 & 0.932 & 0.002 & 0.897 \\
\hline 10 & $(3)+(9)=0$ & -0.081 & 0.001 & -0.081 & 0.001 \\
\hline$R^{2}$ & & 0.780 & & 0.780 & \\
\hline Adjust & $\mathrm{d} R^{2}$ & 0.730 & & 0.720 & \\
\hline Durbin & Watson stat & 2.040 & & 2.040 & \\
\hline Month & y Dummies & Yes & & Yes & \\
\hline Trend & & No & & Yes & \\
\hline \multicolumn{6}{|c|}{$\begin{array}{l}\text { The dependent variable } P S C_{t} \text { is the growth in the total amount of the loans granted to } \\
\text { the private sector by banking system in month } t \text {. The independent variables are: } \\
P S C_{t-j} \text { which is the growth of the total amount of the loans granted to the private } \\
\text { sector by banking system in month } t-j, G B_{t-j} \text { which is the growth in government } \\
\text { borrowing in month } t-j, L C_{t-j} \text { which is the growth in the lending capacity of the banks } \\
\text { measured by the total deposits net of reserves. IPLS } M_{t-j} \text { which is growth in the index } \\
\text { of Industrial Production/Large Scale Manufacturing and } C P I_{t-j} \text { which is CPI inflation. } \\
\text { The estimations use } 206 \text { monthly observations. }\end{array}$} \\
\hline
\end{tabular}

